\title{
Robotic Restaurant Marketing Strategies in the Era of the Fourth Industrial Revolution: Focusing on Perceived Innovativeness
}

\author{
Jinsoo Hwang ${ }^{1} \mathbb{D}$, Kwang-Woo Lee ${ }^{2}$, Dohyung Kim ${ }^{3}$ and Insin Kim ${ }^{4, * \mathbb{D}}$ \\ 1 The College of Hospitality and Tourism Management, Sejong University, 98 Gunja-Dong, Gwanjin-Gu, \\ Seoul 143-747, Korea; jhwang@sejong.ac.kr \\ 2 Department of Tourism Management, College of Economics and Business Administration, Daegu University, \\ Daegu, Kyungsansi, Kyungsangbukdo 38453, Korea; kw.lee@daegu.ac.kr \\ 3 Seoulland F\&B, 181, Gwangmyeong-ro, Gwacheon-si, Gyeonggi-do 13829, Korea; dhkim@seoulland.co.kr \\ 4 Department of Tourism and Convention, Pusan National University, Busan 43241, Korea \\ * Correspondence: insinkim@pusan.ac.kr
}

Received: 7 October 2020; Accepted: 21 October 2020; Published: 4 November 2020

\begin{abstract}
Although innovative robotic technology plays an important role in the restaurant industry, there is not much research on it. Thus, this study tried to identify how to form behavioral intentions using the concept of perceived innovativeness in the context of robotic restaurants for the first time. A research model comprising 12 hypotheses is evaluated using structural equation modeling based on a sample of 418 subjects in South Korea. The data analysis results show that perceived innovativeness is an important predictor of the customers' attitude, which in turn has a significant effect on desire. In addition, desire exerts a positive influence on intentions to use and willingness to pay more. Lastly, perceived risk moderates the relationships between (1) desire and intentions to use and (2) desire and willingness to pay more. Based on the above statistical results, important theoretical and managerial implications are presented.
\end{abstract}

Keywords: robotic restaurants; perceived innovativeness; perceived risk; attitude; behavioral intentions

\section{Introduction}

Innovative technology affects organizations and entire industries [1]. Recently, innovative robotic technology has been attracting worldwide attention. Companies have heavily invested in robotic technology to replace repetitive and tedious tasks with innovative technologies $[2,3]$. Furthermore, such robotic technology plays an important role in improving the quality of service industry-wide $[4,5]$, including the restaurant industry which, is making increasing use of robotic technology [6,7]. The many issues of the restaurant industry, such as congestion during high volume times or having enough qualified servers, can be overcome by robotic technology systems [8]. In particular, robotic technology has a significant effect on lowering labor costs, with its capability for welcoming visitors, taking orders, cooking food, and even serving food [9]. A restaurant that uses robotic technology to provide services for its customers is called a robotic restaurant [10]. Even though robotic restaurants are commercially available all over the world, relevant academic research has remained inadequate [11,12].

The innovativeness of new products/services such as robotic restaurants is critical for building a successful business model because it significantly affects the consumer's decision-making process in the adoption of the new products/services $[13,14]$. When consumers perceive a high level of innovativeness from a new product/service, they tend to try the new product/service. From the consumers' point of view, perceived innovativeness is a company's effort to satisfy the needs of consumers who are 
eager to have new technology-based services [15]. More importantly, understanding the perceived innovativeness of new products/services is very meaningful and important, because it is directly related to a company's financial condition [16,17]. Even though perceived innovativeness is significant, there is no research about it in the field of robotic restaurants.

Perceived risk has a large influence on consumers' adoption of new technology-based services $[18,19]$. Perceived risk means worrying about the negative consequences of buying a new product [20]. For instance, if consumers perceive high risks regarding using robotic restaurants, they are less likely to use the restaurants than those who perceive low risks regarding using the restaurants, which suggests that perceived risk plays an important moderating role and that consumers' decisions on whether to use new technology-based services are affected by the level of perceived risk. Thus, this study investigated the moderating role of perceived risk in the context of robotic restaurants for the first time.

In summary, the current study attempts to fill in the gaps in the literature outlined above by empirically investigating the importance of perceived innovativeness in robotic restaurants. More specifically, the study objectives are to (1) identify the influences of perceived innovativeness on attitude; (2) identify the effects of attitude on desire and behavioral intentions, which include intentions to use and willingness to pay more; (3) identify the relationship between desire and behavioral intentions; and (4) identify the moderating role of perceived risk in the proposed model.

\section{Literature Review}

\subsection{Background of Robotic Restaurants}

In the fourth industrial revolution, we are witnessing significant advances globally with robotics, which has impacted management systems $[3,21]$, particularly in the service industry. Since the service sector industry contributes to $65 \%$ of the worldwide GDP [22], the service robotics market automation is increasing quicker than in other sectors, so it is a fundamental and integral sector [23]. The sales volume of service robots expanded by 39\% to 6.6 billion dollars from 2016 to 2017 [24]. In the restaurant industry, robotics are also attracting attention because they help to minimize expenses by raising efficiencies in terms of the speed of the service, order processing, and labor and stock management $[7,8]$, so there are currently many robotic restaurants worldwide.

For example, in April 2010, a new Japanese Hajime robot eatery opened in Thailand, which had four robot waiters as part of the staff. At every stall, the customers sat along an aisle with an easily used touch screen which they could use to submit their orders. Once the food was prepared, the rolling robots rolled down to the kitchen and brought back the customer's order [7]. The Korean Advanced Institute of Science and Technology has been experimenting with developing an emotionally interactive service robot for the restaurant industry by utilizing emotional interaction technologies between humans and robotics. The touch screens on the robots have a service menu application, which contains various applications for the customers. The service menu has information, such as weather and news, and entertainment, such as games and videos [7]. In November 2018, the enormous online Chinese retailer JD.com opened the first completely automated robotic restaurant that included all processes, such as ordering, preparing food, cooking, plating, and waiting tables. The company reported plans to create up to 1000 more of these places by 2020 [1].

Robotic automation can perform some of the more difficult service jobs, such as being a culinary specialist or a barista in a coffeehouse or other eateries. For instance, robotic bartenders have been installed on the newest Royal Caribbean Cruises, which were able to blend two beverages per minute, to offer a menu of 21 different mixed drinks, and to deal with customer orders [25]. Another cafe opened in February 2018 in the business area of Shibuya, Tokyo, Japan, with a one-armed robot named Sawyer acting as a barista. The robot takes orders and can converse with the customers. Sawyer can serve up to five clients and only takes a couple of minutes to complete an order [1]. Moreover, Moley Robotics, which is a robotics company, has created a humanoid culinary expert known as The Moley Robotic Kitchen. It can learn and emulate the movements of a human chef preparing and cooking a requested 
meal. The results found that the dishes are cooked more consistently in terms of quality than those that were created by a human gourmet expert [26]. The Moley Robotic Kitchen has the ability to prepare more than 100 distinct dishes while giving boundless access to many different gourmet specialists and their recipes [27]. Its advantage is that the cooking procedures are accurately and precisely set and then followed exactly and precisely step-by-step every time without mistake. However, the only deviation in food quality is due to the quality of the raw ingredients provided to the robotic chef [28].

In summary, the restaurant industry is a diverse and exceptionally competitive field that is one of the quickest developing service segments with the potential development of new technologies $[29,30]$. Thus, robotic restaurants are essential to improve the service quality and the efficient management in the restaurant industry $[9,31]$. Therefore, robotic restaurants are expected to continue to develop, but there is very little research them it in the literature.

\subsection{Perceived Innovativeness}

Research related to perceived innovativeness in the context of new technology has been going on continuously [32-35]. In particular, the importance of the concept is becoming more prominent during the fourth industrial revolution. Perceived innovativeness refers to "the degree to which consumers believe that the product possesses important attributes of innovation such as newness and uniqueness" [36] (p. 266). The original and creative attributes of products/services are the significant standards to evaluate the level of perceived innovativeness [37]. Perceived innovativeness originated from the theory of innovativeness [38], which suggests that the individual's level of innovativeness aids in attaining better solutions to problems. When consumers perceive high levels of innovativeness from new high-tech products, they believe that the products are superior to the existing products. Thus, perceived innovativeness is considered a key factor to make advanced market strategies [13,39], which helps to distinguish a particular company from competitive companies [40].

In the new technology industry, perceived innovativeness has a large effect on the growth and development of the company, because it is the most important evaluation criterion of new technology-based products [41]. Pappu and Quester [42] also suggested that perceived innovativeness has a direct impact on a company's sales in the high-technology industry, so it is essential to survive the fierce competition. Empirical research has also demonstrated the correlation between perceived innovativeness and firm performance. For instance, Kleinschmidt and Cooper [43] suggested that highly innovative products lead to a greater return on investment when compared with moderately innovative products. In addition, Langerak and Hultink [44] showed that perceived innovativeness has a significant impact on the purchase decision-making process and consequently improves corporate performance. Jalilvand [17] also argued that perceived innovativeness is central to a hospitality firm's success because it is a key factor that affects a hotels' performance. Parida et al. [45] found that perceived innovativeness plays an important role in improving corporate performance.

\subsection{Effect of Perceived Innovativeness on Attitude}

First, the current study examined the influence of perceived innovativeness on customers' attitudes towards using robotic restaurants. Attitude is defined as "the degree to which a person has a favorable or unfavorable evaluation or appraisal of the behavior" [46], which suggests that attitude reflects a consumer's favorable or unfavorable appraisal of a certain action [47,48]. More importantly, attitude towards a certain product/service can be generated by an individual's second-hand experiences, such as prior knowledge or information regarding the products/services, even though he/she has no experience of using the products/services [49]. In the same vein, Ajzen and Fishein [50] suggested that subjective beliefs play a critical role in the formation of attitude towards a certain product/service. Thus, it can be proposed that perceived innovativeness, which is deemed a subjective belief, has a significant influence on individual attitude.

Prior empirical studies also suggested the effect of perceived innovativeness on attitude. For instance, Watchravesringkan et al. [36] developed a theoretical model to identify how perceived 
innovativeness helps to enhance attitudes, both utilitarian and hedonic, using 268 subjects in the field of technological fashion products. They indicated that perceived innovativeness is a significant factor that affects the two dimensions of attitude. Boisvert and Ashill [51] also investigated the effect of perceived innovativeness on attitude using 664 subjects in the service industry. The results of the data analysis showed that there is a positive relationship between perceived innovativeness and attitude. More recently, Hwang, Lee et al. [13] tested the role of perceived innovativeness in the formation of attitude using 324 subjects in the context of drone food delivery services, and they suggested that perceived innovativeness positively affects attitude. When consumers perceive that drone food delivery services are innovative, they are more likely to have a favorable attitude towards using the services. Based on the theoretical and empirical backgrounds that are discussed above, the following hypothesis is proposed:

Hypothesis 1 (H1). Perceived innovativeness has a positive influence on attitude.

\subsection{Effect of Attitude on Desire}

Second, this study proposed the effect of attitude on desire. Desire is defined as "a state of mind whereby an agent has a personal motivation to perform an action or to achieve a goal" [52] (p. 71). Desire is generated through a favorable or unfavorable assessment, and has a strong influence on the consumers' future behavioral intentions [53]. Similarly, the model of goal-directed behavior (MGB) suggested that consumers have a greater desire to take a certain action when they have a favorable attitude towards the action [54].

Previous research also provided the rationale for the relationship between attitude and desire. For instance, Lee et al. [55] examined the relationship between attitude and desire using 397 subjects in the tourism industry. They found that when tourists have a favorable attitude toward visiting a certain destination, they desire to visit the destination. In addition, Han and Yoon [56] analyzed 384 subjects in order to examine how attitude affects desire in the hotel industry. They showed that when hotel guests have a good attitude towards using an environmentally responsible hotel, they have a greater desire to use the hotel. Hwang, Kim, and Kim [57] explored the effect of attitude on desire using 320 subjects in the context of drone food delivery services. Their data analysis results revealed a positive relationship between attitude and desire. That is, if consumers have a positive attitude towards using drone food delivery services when ordering food, their desire to use the services is strong. Incorporating these theoretical and empirical backgrounds, this study proposes the following hypothesis:

Hypothesis 2 (H2). Attitude has a positive influence on desire.

\subsection{Effect of Attitude on Behavioral Intentions}

Behavioral intentions refer to "a stated likelihood to engage in a behavior" [58] (p. 28). Prior studies have suggested the following two sub-dimensions of behavioral intentions that include intentions to use and willingness to pay more, either individually or collectively, in consumer behavior research [59-61]. Intentions to use are defined as "the degree to which a person has formulated conscious plans to perform or not perform some specified future behavior" [62] (p. 214), while the willingness to pay more refers to the maximum price a customer intends to pay for a product/service $[63,64]$. Existing theories, such as the technology acceptance model and the theory of planned behavior, argue that an individual's behavioral intentions to use a certain product/service is formed by his/her favorable evaluation of the product/service [65,66], which suggests that attitude is a key predictor of behavioral intentions.

Previous studies in the consumer field also supported this argument. For example, $\mathrm{Wu}$ and Chen [67] explored the role of attitude as a predictor of behavioral intentions using 252 students who have taken massive open online courses. The data analysis results indicated that attitude has a positive influence on behavioral intentions. Meng and Han [68] developed a theoretical model in 
order to identify the relationship between attitude and behavioral intentions using 369 subjects in the tourism industry. They found that when tourists have a positive attitude towards working-holiday traveling, they are more likely to go working-holiday traveling in the future. In addition, Hwang and Kim [69] also examined how attitude affects behavioral intentions in the context of drone food delivery services. They analyzed 427 subjects and revealed that attitude plays a significant role in the formation of behavioral intentions. Based on the above discussions, the following hypotheses are proposed.

Hypothesis 3 (H3). Attitude has a positive influence on intentions to use.

Hypothesis 4 (H4). Attitude has a positive influence on willingness to pay more.

\subsection{Effect of Desire on Behavioral Intentions}

The MGB suggested that an individual's behavioral intentions are generated from an internal stimulation, such as desire [52]. Similarly, the attention, interest, desire, and actions model showed that desire helps to enhance behavioral intentions [70,71]. For example, if a consumer has a greater desire to use robotic restaurants, he/she is more likely to use the restaurants.

Empirical research has also proved the relationship between desire and behavioral intentions. Esposito et al. [72] collected data from 400 young adult internet users in order to test the relationship between desire and behavioral intentions. They found that desire aids in enhancing behavioral intentions. Song et al. [73] investigated how desire affects behavioral intentions using 648 subjects in the tourism industry. The data analysis results indicated that desire plays an important role in the formation of behavioral intentions. Recently, Hwang, Cho, and Kim [74] developed a research model in order to examine the effect of desire on behavioral intentions using 397 subjects in the context of drone food delivery services. They suggested that when consumers have a greater desire to use drone food delivery services, they tend to use the services. Therefore, the following hypotheses are proposed.

Hypothesis 5 (H5). Desire has a positive influence on intentions to use.

Hypothesis 6 (H6). Desire has a positive influence on willingness to pay more.

\subsection{Moderating Role of Perceived Risk}

The concept of perceived risk was first introduced by Bauer [75], and many scholars have continued to use the concept to describe consumer behavior in the field of new technology-based services that include electronic commerce, e-services, internet banking, mobile payments, and online shopping [18,74-79]. Cox and Rich [80] (p. 33) defined perceived risk as "the nature and amount of risk perceived by a consumer in contemplating a particular purchase decision". Perceived risk results from unexpected negative consequences for a new product/service, because consumers have had no previous experience with the product/service before [19], so the perceived risk is also known as "a possible loss" [81] (p. 54). Consumers are reluctant to purchase a new product/service if they perceive a high risk, even if the benefits of the product/service are significant $[82,83]$. Therefore, it is important to identify how the perceived risk of a new product/service affects the decision to purchase the product/service.

More importantly, perceived risk plays an important moderating role in the field of new technology, because the adoption of new technology-based products/services depends on the level of risk from the products/services perceived by the consumer [84,85]. Empirical studies have also supported this argument. For instance, Featherman and Fuller [86] explored the moderating role of perceived risk using the technology acceptance model in the context of e-payments. They found that as the level of perceived risk increases, the relationship between ease of use and perceived usefulness weakens. Chang and Chin [87] investigated perceived risk as a moderator using 396 subjects in the 
online shopping industry. They found that perceived risk plays an important moderating role in the relationship between recommendation sources and online purchase intentions. Ramanathan [88] analyzed the ratings for 490 websites in order to find the moderating role of perceived risk. The author suggested that the impact of the logistics performance on customer loyalty varied according to the level of perceived risk. Belanche, Casaló, and Guinalíu [89] examined the moderating role of perceived risk using 214 consumers in the online market industry. They found that perceived risk moderates the relationship between perceived usability and consumer satisfaction. Based on the theoretical and empirical backgrounds, the following hypotheses are proposed.

Hypothesis 7a (H7a). Perceived risk moderates the relationship between perceived innovativeness and attitude.

Hypothesis $7 \mathbf{b}(\mathbf{H 7 b})$. Perceived risk moderates the relationship between attitude and desire.

Hypothesis 7c (H7c). Perceived risk moderates the relationship between attitude and intentions to use.

Hypothesis $\mathbf{7 d}(\mathbf{H 7 d})$. Perceived risk moderates the relationship between attitude and willingness to pay more.

Hypothesis 7e (H7e). Perceived risk moderates the relationship between desire and intentions to use.

Hypothesis $7 \mathbf{f}(\mathbf{H 7 f})$. Perceived risk moderates the relationship between desire and willingness to pay more.

\subsection{Proposed Model}

The research model based on the hypotheses presented in the literature review section is proposed and shown in Figure 1.

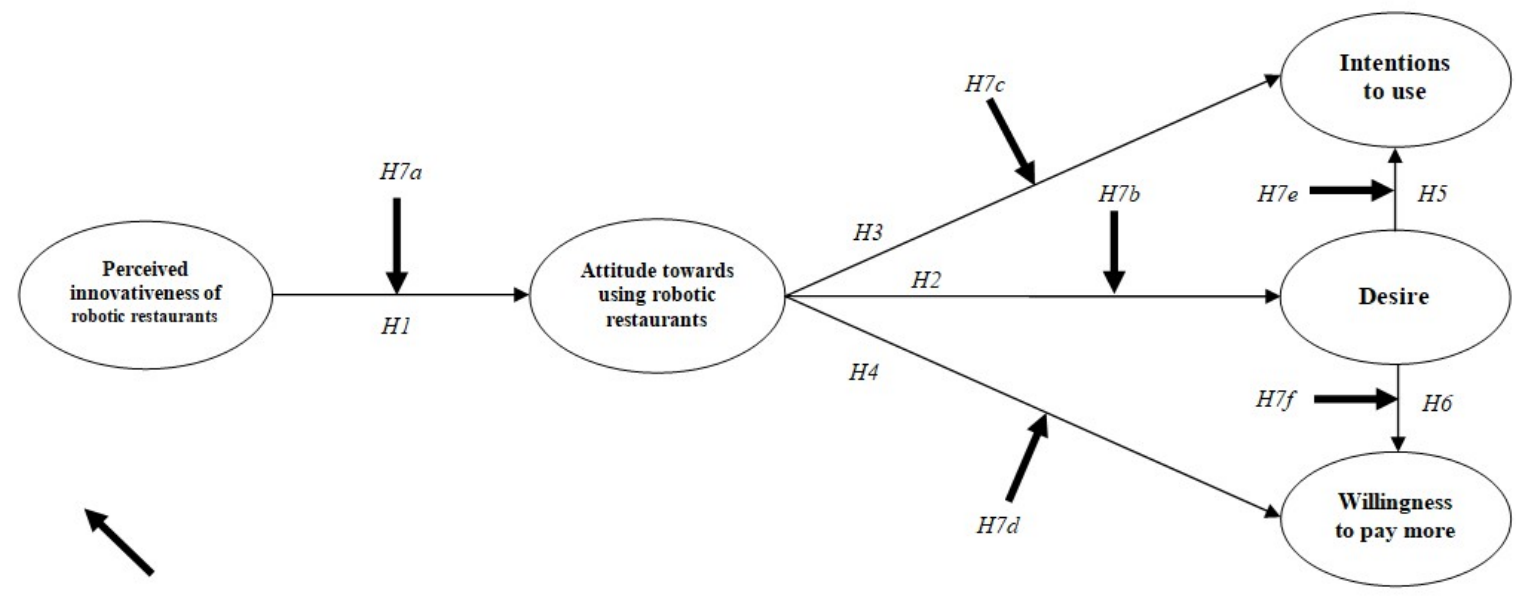

Hypothesized moderating role of perceived risk $(\mathrm{H} 7 \mathrm{a}-\mathrm{f})$

Figure 1. The proposed conceptual model.

\section{Methodology}

\subsection{Measures}

A questionnaire was developed based on the measurement items that have proven to be reliable and valid in previous studies (see Table A1 in the Appendix B). First, perceived innovativeness was measured with three items that were adapted from Fu and Elliott [90] and Hwang, Lee et al. [13]. Second, attitude was measured using the three items adapted from Bagozzi, Dholakia, and Basuroy [91]. Third, desire was measured with three items borrowed from Perugini and Bagozzi [92]. Fourth, the three measurement items for intentions to use were adapted from Zeithaml, Berry, and Parasuraman [93]. 
Fifth, willingness to pay more was measured using the three items employed by Kiatkawsin and Han [94]. Lastly, perceived risk was measured with three items adapted from Chen [95] and Hwang and Choe [96] (i.e., A robotic restaurant does not seem to perform well; The probability that something's wrong with the performance of a robotic restaurant is high; Considering the expected level of performance of a robotic restaurant, it would be risky to use it). All of the questions were quantified using a seven-point Likert-type scale that ranged from strongly disagree (1) to strongly agree (7).

\subsection{Data Collection}

Before the main data collection, this study conducted a pretest using 50 restaurant customers in South Korea. The result of data analysis showed that the values of Cronbach's alpha were higher than 0.07 , which indicated a high level of reliability. In addition, an online survey was used for the main data collection through a survey company in South Korea. Since the background of this study is robotic restaurants, which are not yet active in South Korea, two videos, which clearly explain about a robotic restaurant, were provided to the respondents before the survey (see Figures A1 and A2 in the Appendix A). An online survey was distributed to 1798 restaurant customers. Among them, 465 respondents participated in the survey. In addition, a Mahalanobis distance check and a visual inspection were employed to check the multivariate outliers among the 465 respondents, which resulted in 47 outliers being removed. As a result, 418 usable responses were retained for further analysis

\section{Data Analysis and Results}

\subsection{Descriptive Statistics}

Table 1 provides the demographic characteristics of the sample. In the collected data set $(n=418)$, $50.2 \%$ of the respondents were female $(n=210)$. The highest percentage of participants were in their $20 \mathrm{~s}(\mathrm{n}=147,35.2 \%)$. In addition, the average age was 36.74 years old. In terms of monthly household income, $27.8 \%(\mathrm{n}=116)$ reported a monthly house income that ranged from US $\$ 1001$ to US $\$ 2000$. In the case of marital status, the largest category was single $(n=229,54.8 \%)$. Lastly, the majority of the respondents possessed a bachelor's degree $(n=226,54.1 \%)$.

Table 1. Demographic characteristics of the samples $(n=418)$.

\begin{tabular}{ccc}
\hline Variable & $n$ & Percentage \\
\hline Gender & - & - \\
Male & 208 & 49.8 \\
Female & 210 & 50.2 \\
Age & & \\
20 s & 147 & 35.2 \\
30 s & 123 & 28.4 \\
40 s & 83 & 19.9 \\
Over 50s & 65 & 15.6 \\
Average age $=36.74$ years old & - & - \\
Monthly household income & - & - \\
\$6001 and over & 26 & 6.2 \\
\$5001-\$6000 & 8 & 1.9 \\
\$4001-\$5000 & 36 & 8.6 \\
\$3001-\$4000 & 60 & 14.4 \\
\$2001-\$3000 & 97 & 23.2 \\
\$1001-\$2000 & 116 & 27.8 \\
Under \$1000 & 75 & 17.9 \\
Maritalstatus & - & - \\
Single & 229 & 54.8 \\
Married & 182 & 43.5 \\
Widowed/Divorced & 7 & 1.7 \\
\hline
\end{tabular}


Table 1. Cont.

\begin{tabular}{ccc}
\hline Variable & $\boldsymbol{n}$ & Percentage \\
\hline Education Level & - & - \\
Less than high school diploma & 64 & 15.3 \\
Associate's degree & 79 & 18.9 \\
Bachelor's degree & 226 & 54.1 \\
Graduate degree & 49 & 11.7 \\
\hline
\end{tabular}

\subsection{Confirmatory Factor Analysis (CFA)}

Table 1 provides the demographic characteristics of the sample. In the collected data set ( $n=418), 50.2 \%$ of the respondents' confirmatory factor analysis (CFA) was used in order to test the uni-dimensionality of the scales and validate the overall measurement model. The CFA results showed that the measurement model was proven to have a satisfactory fit to the data $(\chi 2=235.255$, $\mathrm{df}=80, \chi 2 / \mathrm{df}=2.941, p<0.001$, Normed Fit Index $(\mathrm{NFI})=0.970$, Comparative Fit Index $(\mathrm{CFI})=0.980$, Tucker-Lewis Index $(\mathrm{TLI})=0.974$, and Root Mean Square Error of Approximation $($ RMSEA $)=0.068$ ) The values of NFI, CFI, and TLI were greater than 0.9, which indicates an acceptable model fit [97]. In addition, an RMSEA value between 0.04 and 0.08 also shows an adequate model fit [97]. As shown in Table 2, all of the standardized loadings were equal to or higher than 0.750 and significant at $p<0.001$.

Table 2. Confirmatory factor analysis: Items and loadings.

\begin{tabular}{cc}
\hline Construct and Scale Items & StandardizedLoading ${ }^{\text {a }}$ \\
\hline Perceived innovativeness & - \\
A robotic restaurant seems unique. & 0.796 \\
A robotic restaurant seems new. & 0.842 \\
A robotic restaurant seems creative. & 0.750 \\
Attitude & - \\
Unfavorable-Favorable & 0.914 \\
Bad-Good & 0.935 \\
Negative-Positive & 0.908 \\
Desire & - \\
I desire to use a robotic restaurant when dining out. & 0.936 \\
My desire of using a robotic restaurant when dining out is strong. & 0.846 \\
I want to use a robotic restaurant when dining out. & 0.957 \\
Intentions to use & - \\
I will use a robotic restaurant when dining out. & - \\
I am willing to use a robotic restaurant when dining out. & 0.935 \\
I am likely to use a robotic restaurant when dining out. & 0.903 \\
Willingness to pay more & 0.960 \\
I am likely to pay more for a robotic restaurant. & - \\
It is acceptable to pay more for a robotic restaurant. & 0.934 \\
I am likely to spend extra in order to use a robotic restaurant. & 0.975 \\
\hline Goodness-of-fit statistics: $\chi^{2}=235.255$, df $=80, \chi^{2} /$ df $=2.941, p<0.001$, NFI $=0.970$, CFI = 0.980, \\
TLI = 0.974, and RMSEA = 0.068 \\
\hline Notes 1: a All factors loadings are significant at $p<0.001$. Notes 2: NFI = Normed Fit Index, CFI = Comparative Fit \\
Index, TLI = Tucker-Lewis Index, and RMSEA = Root Mean Square Error of Approximation.
\end{tabular}

As shown in Table 3, the values of all of the constructs' average variance extracted (AVE) were higher than the 0.50 threshold value [98]. Considering the high standardized loadings of each variable and the acceptable AVE values of all of the constructs, the convergent validity was well achieved [99]. Additionally, the value of AVE for each construct was greater than the square of the coefficient representing its correlation with other constructs, which suggests a satisfactory discriminant validity [99]. Lastly, the values of all of the composite reliability indices exceeded the 0.70 threshold [100], 
which suggests high internal consistency. In summary, the CFA results indicated that there were no issues with convergent validity, discriminant validity, or reliability.

Table 3. Descriptive statistics and associated measures.

\begin{tabular}{ccccccccc}
\hline Items & No. of Item & Mean (SD) & AVE & (1) & (2) & (3) & (4) & (5) \\
\hline (1) Perceived innovativeness & 3 & $5.15(1.03)$ & 0.635 & $\mathbf{0 . 8 3 9 ^ { \mathrm { a } }}$ & $0.601^{\mathrm{b}}$ & 0.554 & 0.562 & 0.369 \\
(2) Attitude & 3 & $4.45(1.45)$ & 0.845 & $0.361^{\mathrm{c}}$ & $\mathbf{0 . 9 4 2}$ & 0.614 & 0.645 & 0.564 \\
(3) Desire & 3 & $3.75(1.37)$ & 0.836 & 0.307 & 0.377 & $\mathbf{0 . 9 3 8}$ & 0.745 & 0.701 \\
(4) Intentions to use & 3 & $4.07(1.31)$ & 0.870 & 0.316 & 0.416 & 0.555 & $\mathbf{0 . 9 5 3}$ & 0.670 \\
(5) Willingness to pay more & 3 & $3.07(1.41)$ & 0.918 & 0.136 & 0.318 & 0.491 & 0.449 & $\mathbf{0 . 9 7 1}$ \\
\hline
\end{tabular}

Notes 1: SD = Standard Deviation and AVE = Average Variance Extracted. Notes 2: a. Composite reliabilities are along the diagonal, b. Correlations are above the diagonal, and c. Squared correlations are below the diagonal.

\subsection{Structural Equation Modeling (SEM)}

Structural equation modeling (SEM) was conducted to empirically assess the proposed hypotheses. The overall fit of the proposed model was adequate $\left(\chi^{2}=240.971, \mathrm{df}=84, \chi 2 / \mathrm{df}=2.869, p<0.001\right.$, $\mathrm{NFI}=0.970, \mathrm{CFI}=0.980, \mathrm{TLI}=0.975$, and RMSEA $=0.067$ ). Table 4 shows the detailed results from the hypothesis testing. The SEM results statistically supported five of the six hypotheses. More specifically, perceived innovativeness had a positive influence on attitude $(\beta=0.610, p<0.05)$, so Hypothesis 1 was supported. Attitude enhanced desire $(\beta=0.818, p<0.05)$ and intentions to use $(\beta=0.222, p<0.05)$; hence Hypotheses 2 and 3 were supported. However, the result showed that there was no relationship between attitude and willingness to pay more, so Hypothesis 4 was not supported. Lastly, desire had a significant influence on intentions to use $(\beta=0.763, p<0.05)$ and willingness to pay more $(\beta=0.722$, $p<0.05)$; therefore, Hypotheses 5 and 6 were statistically supported.

Table 4. Standardized parameter estimates for structural model.

\begin{tabular}{cccccc}
\hline Independent Variable & - & Dependent Variable & Coefficients & $\boldsymbol{t}$-Value & Hypothesis \\
\hline H1 Perceived innovativeness & $\rightarrow$ & Attitude & 0.610 & $11.159^{*}$ & Supported \\
H2 Attitude & $\rightarrow$ & Desire & 0.818 & $21.350^{*}$ & Supported \\
H3 Attitude & $\rightarrow$ & Intentions to use & 0.222 & $5.762^{*}$ & Supported \\
H4 Attitude & $\rightarrow$ & Willingness to pay more & 0.024 & 0.333 & Notsupported \\
H5 Desire & $\rightarrow$ & Intentions to use & 0.763 & $18.297^{*}$ & Supported \\
H6 Desire & $\rightarrow$ & Willingness to pay more & 0.722 & $9.998^{*}$ & Supported \\
\hline
\end{tabular}

Goodness-of-fit statistics: $\chi^{2}=240.971, \mathrm{df}=84, \chi^{2} / \mathrm{df}=2.869, p<0.001, \mathrm{NFI}=0.970, \mathrm{CFI}=0.980, \mathrm{TLI}=0.975$, and RMSEA $=0.067$ Notes $1:{ }^{*} p<0.05$. Notes 2: NFI = Normed Fit Index, CFI = Comparative Fit Index, TLI = Tucker-Lewis Index,
and RMSEA $=$ Root Mean Square Error of Approximation.

\subsection{Measurement-Invariance Assessment}

Before checking the moderating role of perceived risk (Hypotheses 7a-f), a measurement invariance test was performed [101]. First, the respondents $(n=418)$ were separated by the median value of perceived risk into low $(n=223)$ and high $(n=195)$ perceived risk groups. As presented in Table 5, the non-restricted model $(\chi 2=378.664, \mathrm{df}=160, p<0.001, \mathrm{NFI}=0.952, \mathrm{CFI}=0.972, \mathrm{TLI}=0.963$, and RMSEA $=0.057)$ and the full-metric invariance model $(\chi 2=419.151, \mathrm{df}=175, p<0.001, \mathrm{NFI}=0.947$, $\mathrm{CFI}=0.968$, TLI $=0.962$, and RMSEA $=0.058$ ) had acceptable fit statistics. In addition, there was no significant difference between the non-restricted model and the full-metric invariance model $\left(\Delta \chi^{2}=30.580<\chi^{2}=0.01(\mathrm{df}=15)=40.487\right)$, which suggests that full metric invariance was supported. 
Table 5. Measurement-invariance models.

\begin{tabular}{|c|c|c|c|c|c|c|c|c|c|}
\hline Moderator & Models & $x^{2}$ & $d f$ & NFI & CFI & TLI & RMSEA & $\Delta x^{2}$ & $\begin{array}{l}\text { Full-Metric } \\
\text { Invariance }\end{array}$ \\
\hline \multirow{2}{*}{$\begin{array}{l}\text { Perceived } \\
\text { risk }\end{array}$} & $\begin{array}{l}\text { Non-restricted } \\
\text { model }\end{array}$ & 378.664 & 160 & 0.95 & 0.97 & 0.96 & 0.057 & \multirow{2}{*}{$\begin{array}{c}\Delta \chi^{2}(15)=40.487 \\
p>0.01 \\
\text { (insignificant) }\end{array}$} & \multirow{2}{*}{ Supported } \\
\hline & $\begin{array}{l}\text { Full-metric } \\
\text { invariance }\end{array}$ & 419.151 & 175 & 0.94 & 0.96 & 0.96 & 0.058 & & \\
\hline
\end{tabular}

Notes 1: NFI = Normed Fit Index, CFI = Comparative Fit Index, TLI $=$ Tucker-Lewis Index, and RMSEA = Root Mean Square Error of Approximation. Notes 2: $\Delta \chi^{2}(15)=30.580$ and $p>0.01$

\subsection{The Moderating Role of Perceived Risk}

Multiple group analysis was conducted in order to empirically assess the moderating role of perceived risk [97]. Using the same method as the measurement-invariance assessment, the respondents were divided into two groups based on the median value of perceived risk, which included the low $(n=223)$ and the high $(n=195)$ perceived risk groups. The chi-square difference between the constrained and the unconstrained models was assessed by considering the difference in the degrees of freedom in order to statistically test the differential effects of the perceived risk between these two groups.

First, the results of the multiple-group analyses indicated that perceived risk plays a moderating role in the relationship between desire and intentions to use $(\Delta \chi 2=4.125>\chi 2=0.05(1)=3.84$, and $\mathrm{df}=1)$, which supports Hypothesis 7e. More specifically, the path coefficient for the low perceived risk group ( $\beta=0.798)$ was higher than that for the high perceived risk group $(\beta=0.717)$. Second, the moderating role of perceived risk in the relationship between desire and willingness to pay more was confirmed $\left(\Delta \times 2=7.553>\chi^{2}=0.05(1)=3.84\right.$, and $\left.\mathrm{df}=1\right)$. This result showed that the effect of desire on willingness to pay more was significantly different across the level of perceived risk, which supported Hypothesis $7 \mathrm{f}$. The path coefficient between desire and willingness to pay more was $0.887(p<0.05)$ for the low perceived risk group and $0.581(p<0.05)$ for the high perceived risk group. However, contrary to our expectations, Hypotheses $7 \mathrm{a}\left(\Delta \chi^{2}=0.665<\chi 2=0.05(1)=3.84\right.$, and $\left.\mathrm{df}=1\right), 7 \mathrm{~b}(\Delta \chi 2=1.658<\chi 2=$ $0.05(1)=3.84$, and $\mathrm{df}=1), 7 \mathrm{c}(\Delta \times 2=0.354<\chi 2=0.05(1)=3.84$, and $\mathrm{df}=1)$, and $7 \mathrm{~d}(\Delta \times 2=2.173<$ $\chi^{2}=0.05(1)=3.84$, and $\mathrm{df}=1$ ) were not statistically supported. Figure 2 presents the results of the multiple-group analyses.

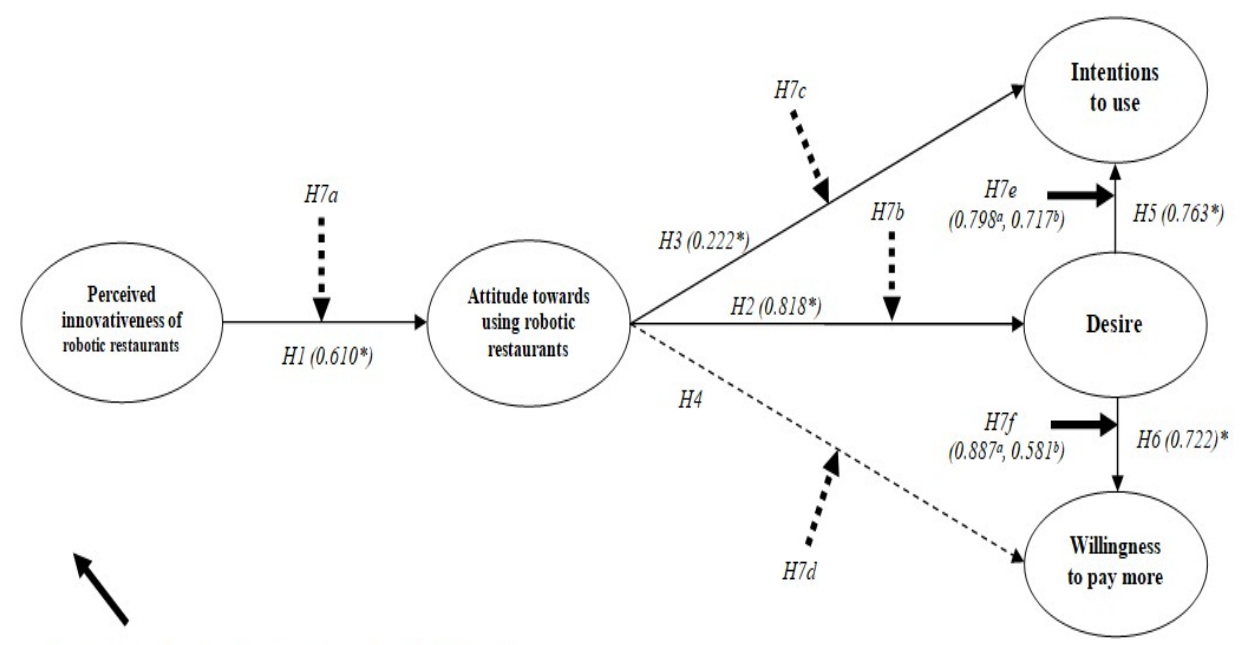

Hypothesized moderating role of perceived risk (H7a-f)

Figure 2. Standardized theoretical path coefficients. Notes 1: ${ }^{*} p<0.05$ Notes 2: The dashed line indicates the non-significant path $(p>.05)$. Notes 3: $\mathrm{a}=$ Path coefficient for the low perceived risk group and $b=$ path coefficient for the high perceived risk group. 


\section{Discussions and Implications}

\subsection{Theoretical Implications}

First, the data analysis results verified the relationship between perceived innovativeness and attitude $(\beta=0.610$ and $p<0.05)$, which can be interpreted as showing that when consumers feel that a robotic restaurant seems creative, they are more likely to have a favorable attitude towards using the restaurant. In the history of new technology research, scholars also found the significance of perceived innovativeness $[13,36,51]$, which suggested that perceived innovativeness plays an important role in the formation of a favorable attitude towards using new technology-based services. Unlike previous studies, this study revealed for the first time that perceived innovativeness helps to enhance attitude in the context of a robotic restaurant. In this regard, this study confirmed and also extended the important role of perceived innovativeness by empirically finding the effect of perceived innovativeness on attitude.

Second, the data analysis results showed that attitude has a significant effect on desire $(\beta=0.610$ and $p<0.05)$ and intentions to use $(\beta=0.610$ and $p<0.05)$. In other words, when consumers have a positive attitude towards using a robotic restaurant, their desire to use the restaurant is stronger, and they are also more likely to use the restaurant when dining out. These findings are consistent with prior studies [56,67], which suggested that attitude is a critical factor that affects desire and intentions to use. When compared with the previous studies, the theoretical implications of these findings indicate that for the first time in the context of a robotic restaurant, the effect of attitude on desire and intentions to use was revealed.

Third, another important theoretical implication of this study involved finding the outcome variables of desire. Our results indicated the prominent role of desire by generating the two dimensions of behavioral intentions, which include intentions to use and willingness to pay more. It is widely accepted that desire is a personal motivation to take a certain action [52], which means that desire is an important predictor of behavioral intentions. The results of this study supported the argument. That is, when consumers desire to use a robotic restaurant when dining out, they are willing to use and pay more for the restaurant. Extending the role of desire to the field of a robotic restaurant is an important theoretical implication of this study.

Lastly, this study employed multiple-group analyses to test the moderating role of perceived risk. The results showed that perceived risk plays a moderating role in the relationship between (1) desire and intentions to use and (2) desire and willingness to pay more. These results can be interpreted as showing that when consumers have low levels of perceived risk of using a robotic restaurant desire to use a robotic restaurant, they are more likely to use and pay more for the restaurant. On the contrary, although consumers who perceived a strong risk of using a robotic restaurant have a greater desire to use the restaurant, they are less likely to use and spend extra for the restaurant. These study results are consistent with the results of previous studies [86,87,89], which indicate that perceived risk has a negative influence on behavioral intentions. Consequently, the current study confirmed and further extended the existing literature by empirically finding the moderating role of perceived risk in the context of a robotic restaurant for the first time.

\subsection{Managerial Implications}

First and foremost, restaurant companies operating a robotic restaurant are required to emphasize the innovativeness of the robotic restaurant to consumers. For example, it is recommended to emphasize that robot chefs cook according to pre-programmed recipes, so they can serve food quickly to the customers. In addition, human chefs can vary their food quality depending on their condition, but the robot chefs can provide foods with consistent quality under any circumstances. More importantly, chefs are often hurt by cooking accidents in restaurants. It is therefore worthwhile to emphasize that a robot chef is a solution to reduce the risk of such injuries. Lastly, robotic restaurants are also innovative in terms of food prices. It is widely known that labor costs are one of the highest costs in the restaurant industry [102]. In particular, in the case of Korea, the minimum wage is rising, which places a heavy 
burden on managers [103]. This rise in labor costs naturally leads to a rise in food prices. In this regard, robotic restaurants can reduce the burden on labor costs from managers and lower food prices as a result.

Second, this study found an important moderating role of perceived risk in the relationship between (1) desire and intentions to use and (2) desire and willingness to pay more. These results indicated that consumer behavioral intentions can vary depending on the level of perceived risk. In general, consumers who want to use new technology-based services are worried about unexpected negative consequences because they have no experience [104]. Thus, there is a need to emphasize to consumers through advertising or promotions that the risk of robotic restaurants is low. For example, it is recommended to show that a human waiter is able to manage 200 meals per day, and a robot waiter is able to manage between 300 and 400 meals per day without mistakes [105]. In addition, it is also good to inform consumers that a robotic chef can provide customers with food services without mistakes because it is based on AI systems [30,31]. These types of efforts would cause consumers to have low perceived risk.

\section{Conclusions}

The current study aimed to identify the importance of perceived innovativeness in the context of robotic restaurants. More specifically, this study proposed that perceived innovativeness helps to enhance attitude. In addition, it was hypothesized that attitude has a positive influence on desire, which in turn positively affects intentions to use and willingness to pay more. Lastly, the moderating role of perceived risk was proposed between each concept. Twelve hypotheses were evaluated based on a sample of 418 subjects in South Korea. The results of data analysis reveal that perceived innovativeness helps to enhance the customers' attitude, which in turn positively affects their desire. In addition, desire has a positive influence on intentions to use and willingness to pay more. Lastly, perceived risk played a moderating role in the relationships between (1) desire and intentions to use and (2) desire and willingness to pay more.

\section{Limitations and Future Research}

Since this study was conducted in South Korea, it is difficult to apply the results of this study to other fields and regions. In particular, no robotic restaurants are operating in South Korea, so the study respondents had no actual experience of using a robotic restaurant. In order to overcome this issue, two videos that fully describe the robotic restaurant were shown, but in future studies, it would be more beneficial to conduct research with customers who have actually used a robotic restaurant. In addition, an online survey, as a convenience sampling technique that is commonly used in social science research, causes selection bias [106], so it would be better to use other types of data collection methods in future studies in order to reduce this bias. Lastly, all five variables were measured at the same time, so it could cause a common method bias. For this reason, it is recommended to collect data at different times in future research [107].

Author Contributions: J.H., K.-W.L., D.K., and I.K. contributed to the conceptualization, formal analysis, investigation, methodology, writing of the original draft, and writing review and editing. All authors have read and agreed to the published version of the manuscript.

Funding: This work was supported by Leaders in INdustry-university Cooperation+ (LINC+), Sejong University, Korea.

Conflicts of Interest: The authors declare no conflict of interest. 


\section{Appendix A Screenshots from the Two Videos}

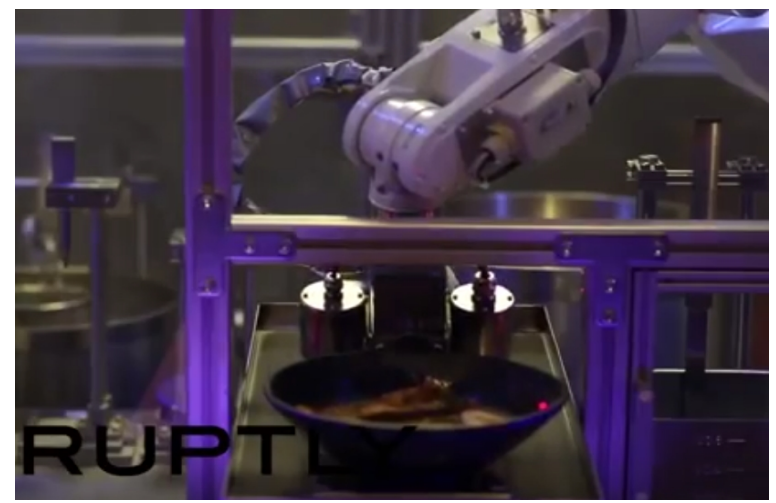

Figure A1. In Robot Ramen restaurant where bots cook. Source from RT UK (2016).

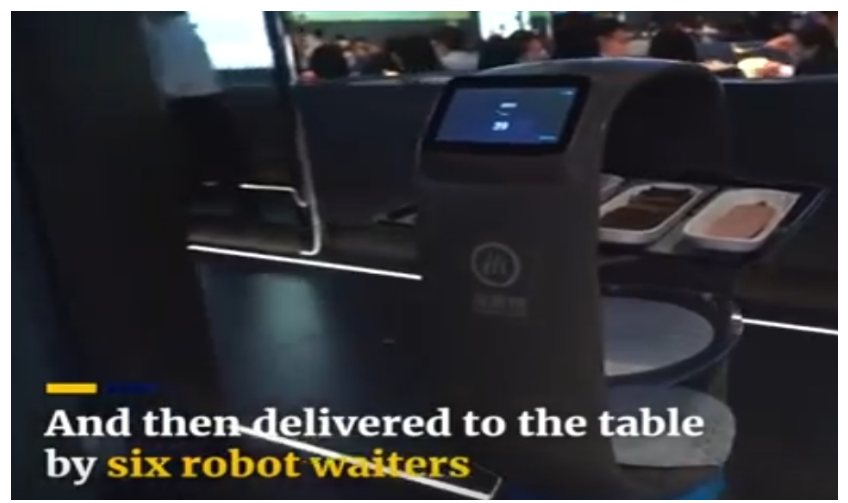

Figure A2. Inside China's first AI hot pot restaurant. Source from South China Morning Post (2018).

\section{Appendix B The Questionnaire}

Please read each item carefully and circle the appropriate number which best reflects your true opinions or feelings.

Table A1. The questionnaire.

\begin{tabular}{cccccccc}
\hline Measurement Items & Strongly Disagree & $\rightarrow$ & Neutral & $\rightarrow$ & \multicolumn{2}{c}{ Strongly Agree } \\
Perceived innovativeness & - & - & - & - & - & - & - \\
A robotic restaurant seems unique. & 1 & 2 & 3 & 4 & 5 & 6 & 7 \\
A robotic restaurant seems new. & 1 & 2 & 3 & 4 & 5 & 6 & 7 \\
A robotic restaurant seems creative. & 1 & 2 & 3 & 4 & 5 & 6 & 7 \\
\hline $\begin{array}{c}\text { Attitude (Attitude toward using } \\
\text { robotic restaurants ...) }\end{array}$ & 1 & & & - & & & \\
$\quad$ Unfavorable-Favorable & 1 & 2 & 3 & 4 & 5 & 6 & 7 \\
$\quad$ Bad-Good & 1 & 2 & 3 & 4 & 5 & 6 & 7 \\
$\quad$ Negative-Positive & & & & 4 & 5 & 6 & 7 \\
\hline
\end{tabular}


Table A1. Cont.

\begin{tabular}{|c|c|c|c|c|c|c|c|}
\hline Desire & - & - & - & - & - & - & - \\
\hline $\begin{array}{l}\text { I desire to use a robotic restaurant } \\
\text { when dining out. }\end{array}$ & 1 & 2 & 3 & 4 & 5 & 6 & 7 \\
\hline $\begin{array}{l}\text { My desire of using a robotic } \\
\text { restaurant when dining out is strong. }\end{array}$ & 1 & 2 & 3 & 4 & 5 & 6 & 7 \\
\hline $\begin{array}{l}\text { I want to use a robotic restaurant } \\
\text { when dining out. }\end{array}$ & 1 & 2 & 3 & 4 & 5 & 6 & 7 \\
\hline Intentions to use & - & - & - & - & - & - & - \\
\hline $\begin{array}{l}\text { I will use a robotic restaurant when } \\
\text { dining out. }\end{array}$ & 1 & 2 & 3 & 4 & 5 & 6 & 7 \\
\hline $\begin{array}{l}\text { I am willing to use a robotic } \\
\text { restaurant when dining out. }\end{array}$ & 1 & 2 & 3 & 4 & 5 & 6 & 7 \\
\hline $\begin{array}{l}\text { I am likely to use a robotic restaurant } \\
\text { when dining out. }\end{array}$ & 1 & 2 & 3 & 4 & 5 & 6 & 7 \\
\hline Willingness to pay more & - & - & - & - & - & - & - \\
\hline $\begin{array}{l}\text { I am likely to pay more for a } \\
\text { robotic restaurant. }\end{array}$ & 1 & 2 & 3 & 4 & 5 & 6 & 7 \\
\hline $\begin{array}{c}\text { It is acceptable to pay more for a } \\
\text { robotic restaurant. }\end{array}$ & 1 & 2 & 3 & 4 & 5 & 6 & 7 \\
\hline $\begin{array}{l}\text { I am likely to spend extra in order to } \\
\text { use a robotic restaurant. }\end{array}$ & 1 & 2 & 3 & 4 & 5 & 6 & 7 \\
\hline Perceived risk & - & - & - & - & - & - & - \\
\hline $\begin{array}{l}\text { A robotic restaurant does not seem to } \\
\text { perform well. }\end{array}$ & 1 & 2 & 3 & 4 & 5 & 6 & 7 \\
\hline $\begin{array}{l}\text { The probability that something's } \\
\text { wrong with the performance of a } \\
\text { robotic restaurant is high. }\end{array}$ & 1 & 2 & 3 & 4 & 5 & 6 & 7 \\
\hline $\begin{array}{l}\text { Considering the expected level of } \\
\text { performance of a robotic restaurant, } \\
\text { it would be risky to use it. }\end{array}$ & 1 & 2 & 3 & 4 & 5 & 6 & 7 \\
\hline
\end{tabular}

\section{References}

1. Verevka, T. Key performance indicators of high-tech enterprises. SHS Web of Conf. 2018, 44, 00077. [CrossRef]

2. Noone, B.M.; Coulter, R.C. Applying Modern Robotics Technologies to Demand Prediction and Production Management in the Quick-Service Restaurant Sector. Cornell Hosp. Q. 2012, 53, 122-133. [CrossRef]

3. Samani, H. The evaluation of affection in human-robot interaction. Kybernetes 2016, 45, 1257-1272. [CrossRef]

4. Lessel, P.; Böhmer, M.; Kröner, A.; Krüger, A. User requirements and design guidelines for digital restaurant menus. In Proceedings of the NordiCHI '12-7th Nordic Conference on Human-Computer Interaction Making Sense Through Design, Copenhagen, Denmark, 14-17 October 2012; pp. 524-533. [CrossRef]

5. Tan, T.-H.; Chang, C.-S. Development and evaluation of an RFID-based e-restaurant system for customer-centric service. Expert Syst. Appl. 2010, 37, 6482-6492. [CrossRef]

6. Murphy, J.; Hofacker, C.; Gretzel, U. Dawning of the age of robots in hospitality and tourism: Challenges for teaching and research. Eur. J. Tour. Res. 2017, 15, 104-111.

7. Pieska, S.; Luimula, M.; Jauhiainen, J.; Spiz, V. Social service robots in wellness and restaurant applications. J. Commun. Comput. 2013, 10, 116-123.

8. Asif, M.; Sabeel, M.; Mujeeb-ur Rahman, K.Z. Waiter robot-solution to restaurant automation. In Proceedings of the 1st Student Multi Disciplinary Research Conference (MDSRC), Wah Cantonment, Pakistan, 14-15 November 2015.

9. Huang, G.-S.; Lü, Y.-J. To build a smart unmanned restaurant with multi-mobile robots. In Proceedings of the 2017 International Automatic Control Conference CACS, Pingtung, Taiwan, 12-15 November 2017; pp. 1-6.

10. Hwang, J.; Park, S.; Kim, I. Understanding motivated consumer innovativeness in the context of a robotic restaurant: The moderating role of product knowledge. J. Hosp. Tour. Manag. 2020, 44, 272-282. [CrossRef] 
11. Go, H.; Kang, M.; Suh, S.C. Machine learning of robots in tourism and hospitality: Interactive technology acceptance model (iTAM)-cutting edge. Tour. Rev. 2020, 75, 625-636. [CrossRef]

12. Ivanov, S.; Webster, C. Robots in tourism: A research agenda for tourism economics. Tour. Econ. 2019, 1-21. [CrossRef]

13. Hwang, J.; Lee, J.-S.; Kim, H. Perceived innovativeness of drone food delivery services and its impacts on attitude and behavioral intentions: The moderating role of gender and age. Int. J. Hosp. Manag. 2019, 81, 94-103. [CrossRef]

14. Leckie, C.; Nyadzayo, M.W.; Johnson, L.W. Promoting brand engagement behaviors and loyalty through perceived service value and innovativeness. J. Serv. Mark. 2018, 32, 70-82. [CrossRef]

15. Stock, R.M. How does product program innovativeness affect customer satisfaction? A comparison of goods and services. J. Acad. Mark. Sci. 2010, 39, 813-827. [CrossRef]

16. Eisend, M.; Evanschitzky, H.; Gilliland, D.I. The Influence of Organizational and National Culture on New Product Performance. J. Prod. Innov. Manag. 2015, 33, 260-276. [CrossRef]

17. Jalilvand, M.R. The effect of innovativeness and customer-oriented systems on performance in the hotel industry of Iran. J. Sci. Technol. Policy Manag. 2017, 8, 43-61. [CrossRef]

18. Thakur, R.; Srivastava, M. Adoption readiness, personal innovativeness, perceived risk and usage intention across customer groups for mobile payment services in India. Internet Res. 2014, 24, 369-392. [CrossRef]

19. Tseng, S.-Y.; Wang, C.-N. Perceived risk influence on dual-route information adoption processes on travel websites. J. Bus. Res. 2016, 69, 2289-2296. [CrossRef]

20. Hwang, J.; Choe, J.Y. How to enhance the image of edible insect restaurants: Focusing on perceived risk theory. Int. J. Hosp. Manag. 2020, 87, 102464. [CrossRef]

21. Kanda, T.; Ishiguro, H. Human-Robot Interaction in Social Robotics; CRC Press: Boca Raton, FL, USA, 2017.

22. The World Bank. World Development Indicators: Structure of output. Available online: http://wdi.worldbank. org/table/4.2. (accessed on 2 September 2020).

23. Verevka, T.V. Development of Industry 4.0 in the Hotel and Restaurant Business. IBIMA Bus. Rev. 2019, 1-12. [CrossRef]

24. International Federation of Robotics. Service Robot Report, Executive Summary World Robotics 2018 Service Robots. Available online: https://ifr.org/downloads/press2018/Executive_Summary_WR_Service_Robots_ 2018.pdf. (accessed on 2 September 2020).

25. Alexis, P. R-tourism: Introducing the potential impact of robotics and service automation in tourism. Ovidius University of Constantza, Faculty of Economic Sciences. Ser. Econ. Sci. 2017, 0, 211-216.

26. Marwala, L.; Nkomfe, M. The Fourth Industrial revolution and the case for equitable distribution of income. Enrich The Rich Damn Poor. 2017.

27. Eustacia, H.; Forbes. The World's First Home Robotic Chef Can Cook Over 100 Meals. Available online: https://www.forbes.com/sites/eustaciahuen/2016/10/31/the-worlds-first-home-robotic-chef-can-cook-over100-meals/\#172bb8357228 (accessed on 2 September 2020).

28. Thazin, Y.; Pobkrut, T.; Kerdcharoen, T. Prediction of acidity levels of freshroasted coffees using e-nose and artificial neural network. In Proceedings of the 10th International Conference on Knowledge and Smart Technology KST, Chiang Mai, Thailand, 31 January-3 February 2018; pp. 210-215.

29. Chen, T.F.; Tan, T.-F.; Chen, L.-C.; Lai, P.-C.; Chung, P.-L. R-Tourism: Applications and Incorporation of Robotics and Service Automation in Tourism and Hospitality. Int. J. e-Educ. e-Bus. e-Manag. e-Learn. 2019, 9. [CrossRef]

30. Goertzel, B.; Hanson, D.; Yu, G. A Software Architecture for Generally Intelligent Humanoid Robotics. Procedia Comput. Sci. 2014, 41, 158-163. [CrossRef]

31. Bollini, M.; Tellex, S.; Thompson, T.; Roy, N.; Rus, D. Interpreting and Executing Recipes with a Cooking Robot; Springer Science and Business Media LLC: Heidelberg, Germany, 2013; pp. 481-495.

32. Chauhan, V.; Yadav, R.; Choudhary, V. Analyzing the impact of consumer innovativeness and perceived risk in internet banking adoption. Int. J. Bank Mark. 2019, 37, 323-339. [CrossRef]

33. Johnson, J.D.; Donohue, W.A.; Atkin, C.K.; Johnson, S. Communication, Involvement, and Perceived Innovativeness. Group Organ. Manag. 2001, 26, 24-52. [CrossRef]

34. Ostlund, L.E. Perceived Innovation Attributes as Predictors of Innovativeness. J. Consum. Res. 1974, 1, 23-29. [CrossRef]

35. Zolfagharian, M.A.; Paswan, A. Perceived service innovativeness, consumer trait innovativeness and patronage intention. J. Retail. Consum. Serv. 2009, 16, 155-162. [CrossRef] 
36. Watchravesringkan, K.; Hodges, N.N.; Kim, Y. Exploring consumers' adoption of highly technological fashion products. J. Fash. Mark. Manag. Int. J. 2010, 14, 263-281. [CrossRef]

37. Hwang, J.; Hyun, S.S. Perceived Firm Innovativeness in Cruise Travelers' Experience and Perceived Luxury Value: The Moderating Effect of Advertising Effectiveness. Asia Pac. J. Tour. Res. 2015, 21, S101-S128. [CrossRef]

38. Kirton, M. Adaptors and innovators: A description and measure. J. Appl. Psychol. 1976, 61, 622-629.

39. Thong, J.Y. An Integrated Model of Information Systems Adoption in Small Businesses. J. Manag. Inf. Syst. 1999, 15, 187-214. [CrossRef]

40. Seebode, D.; Jeanrenaud, S.; Bessant, J. Managing innovation for sustainability. RED Manag. 2012, 42, 195-206. [CrossRef]

41. Phau, I.; Teah, M.; Lim, A.; Ho, R. A brief affair with underwear: Uniqueness and innovativeness in male underwear brand purchases. J. Glob. Fash. Mark. 2015, 6, 222-235. [CrossRef]

42. Pappu, R.; Quester, P.G. How does brand innovativeness affect brand loyalty? Eur. J. Mark. 2016, 50, 2-28. [CrossRef]

43. Kleinschmidt, E. The impact of product innovativeness on performance. J. Prod. Innov. Manag. 1991, 8, 240-251. [CrossRef]

44. Langerak, F.F.; Hultink, E.J. The Impact of Product Innovativeness on the Link between Development Speed and New Product Profitability. J. Prod. Innov. Manag. 2006, 23, 203-214. [CrossRef]

45. Parida, V.; Pesämaa, O.; Wincent, J.; Westerberg, M. Network capability, innovativeness, and performance: A multidimensional extension for entrepreneurship. Entrep. Reg. Dev. 2016, 29, 1-22. [CrossRef]

46. Ajzen, I. The Theory of Planned Behavior. Organ. Behav. Hum. Decis. Process. 1991, 50, 179-211.

47. Chakravarti, D.; Eagly, A.H.; Chaiken, S. The Psychology of Attitudes. J. Mark. Res. 1997, 34, 298. [CrossRef]

48. Kiatkawsin, K.; Han, H. Young travelers' intention to behave pro-environmentally: Merging the value-belief-norm theory and the expectancy theory. Tour. Manag. 2017, 59, 76-88. [CrossRef]

49. Oliver, R.L. Customer delight: Foundations, findings, and managerial insight. J. Retail. 1997, 73, 311-336. [CrossRef]

50. Ajzen, I.; Fishbein, M. Attitudes and the Attitude-Behavior Relation: Reasoned and Automatic Processes. Eur. Rev. Soc. Psychol. 2000, 11, 1-33. [CrossRef]

51. Boisvert, J.; Ashill, N.J. How brand innovativeness and quality impact attitude toward new service line extensions: The moderating role of consumer involvement. J. Serv. Mark. 2011, 25, 517-527. [CrossRef]

52. Perugini, M.; Bagozzi, R.P. The distinction between desires and intentions. Eur. J. Soc. Psychol. 2004, 34, 69-84. [CrossRef]

53. Han, H.; Meng, B.; Kim, W. Bike-traveling as a growing phenomenon: Role of attributes, value, satisfaction, desire, and gender in developing loyalty. Tour. Manag. 2017, 59, 91-103. [CrossRef]

54. Leone, L.; Perugini, M.; Ercolani, A.P. Studying, Practicing, and Mastering: A Test of the Model of Goal-Directed Behavior (MGB) in the Software Learning Domain. J. Appl. Soc. Psychol. 2004, 34, 1945-1973. [CrossRef]

55. Lee, C.-K.; Song, H.-J.; Bendle, L.J.; Kim, M.-J.; Han, H. The impact of non-pharmaceutical interventions for 2009 H1N1 influenza on travel intentions: A model of goal-directed behavior. Tour. Manag. 2012, 33, 89-99. [CrossRef]

56. Han, H.; Yoon, H.J. Hotel customers' environmentally responsible behavioral intention: Impact of key constructs on decision in green consumerism. Int. J. Hosp. Manag. 2015, 45, 22-33. [CrossRef]

57. Hwang, J.; Kim, H.; Kim, W. Investigating motivated consumer innovativeness in the context of drone food delivery services. J. Hosp. Tour. Manag. 2019, 38, 102-110. [CrossRef]

58. Oliver, R.L. Satisfaction: A Behavioral Perspective on the Consumer, 2nd ed.; M.E. Sharpe: Armonk, NY, USA, 2014.

59. Chua, B.-L.; Kim, H.-C.; Lee, S.; Han, H. The role of brand personality, self-congruity, and sensory experience in elucidating sky lounge users' behavior. J. Travel Tour. Mark. 2018, 36, 29-42. [CrossRef]

60. Han, H.; Kiatkawsin, K.; Jung, H.; Kim, W. The role of wellness spa tourism performance in building destination loyalty: The case of Thailand. J. Travel Tour. Mark. 2017, 35, 595-610. [CrossRef]

61. Trang, H.L.T.; Lee, J.-S.; Han, H. How do green attributes elicit pro-environmental behaviors in guests? The case of green hotels in Vietnam. J. Travel Tour. Mark. 2018, 36, 14-28. [CrossRef]

62. Warshaw, P.R.; Davis, F.D. Disentangling behavioral intention and behavioral expectation. J. Exp. Soc. Psychol. 1985, 21, 213-228. [CrossRef]

63. Cameron, T.A.; James, M.D. Estimating willingness to pay from survey data: An alternative pre-test-market evaluation procedure. J. Mark. Res. 1987, 24, 389-395. [CrossRef]

64. Krishna, A. Effect of dealing patterns on consumer perceptions of deal frequency and willingness to pay. J. Mark. Res. 1991, 28, 441-451. [CrossRef] 
65. Davis, F.D. Perceived usefulness, perceived ease of use, and user acceptance of information technology. Manag. Inf. Syst. Res. Cent. Q. 1989, 13, 319-340. [CrossRef]

66. Fishbein, M.; Ajzen, I. Belief, Attitude, Intention, and Behavior: An Introduction to Theory and Research; Addison-Wesley: Reading, MS, USA, 1975.

67. Wu, B.; Chen, X. Continuance intention to use MOOCs: Integrating the technology acceptance model (TAM) and task technology fit (TTF) model. Comput. Hum. Behav. 2017, 67, 221-232. [CrossRef]

68. Meng, B.; Han, H. Investigating individuals' decision formation in working-holiday tourism: The role of sensation-seeking and gender. J. Travel Tour. Mark. 2018, 35, 973-987. [CrossRef]

69. Hwang, J.; Kim, H. Consequences of a green image of drone food delivery services: The moderating role of gender and age. Bus. Strat. Environ. 2019, 28, 872-884. [CrossRef]

70. Hassan, S.; Nadzim, S.Z.A.; Shiratuddin, N. Strategic Use of Social Media for Small Business Based on the AIDA Model. Procedia Soc. Behav. Sci. 2015, 172, 262-269. [CrossRef]

71. Rawal, P. AIDA marketing communication model: Stimulating a purchase decision in the minds of the consumers through a linear progression of steps. Int. J. Multidiscip. Res. Soc. Manag. Sci. 2013, 1, 37-44.

72. Esposito, G.; Van Bavel, R.; Baranowski, T.; Duch-Brown, N. Applying the Model of Goal-Directed Behavior, Including Descriptive Norms, to Physical Activity Intentions. Psychol. Rep. 2016, 119, 5-26. [CrossRef]

73. Song, H.; Lee, C.-K.; Reisinger, Y.; Xu, H.-L. The role of visa exemption in Chinese tourists' decision-making: A model of goal-directed behavior. J. Travel Tour. Mark. 2016, 34, 666-679. [CrossRef]

74. Hwang, J.; Cho, S.-B.; Kim, W. Consequences of psychological benefits of using eco-friendly services in the context of drone food delivery services. J. Travel Tour. Mark. 2019, 36, 835-846. [CrossRef]

75. Bauer, R.A. Consumer Behavior as Risk Taking. In Dynamic Marketing for a Changing World, Proceedings of the 43rd. Conference of the American Marketing Association Chicago, IL, USA, 15-17 June 1960; American Marketing Association: Chicago, IL, USA; pp. 389-398.

76. Featherman, M.S.; Pavlou, P.A. Predicting e-services adoption: A perceived risk facets perspective. Int. J. Human-Computer Stud. 2003, 59, 451-474. [CrossRef]

77. Kesharwani, A.; Bisht, S.S. The impact of trust and perceived risk on internet banking adoption in India. Int. J. Bank Mark. 2012, 30, 303-322. [CrossRef]

78. Li, Y.H.; Huang, J.W. Applying theory of perceived risk and technology acceptance model in the online shopping channel. World Acad. Sci. Eng. Technol. 2009, 53, 919-925.

79. Pavlou, P.A. Consumer Acceptance of Electronic Commerce: Integrating Trust and Risk with the Technology Acceptance Model. Int. J. Electron. Commer. 2003, 7, 101-134. [CrossRef]

80. Cox, D.F.; Rich, S.U. Perceived risk and customer decision-making: The case of telephone shopping. J. Mark. Res. 1964, 1, 32-39.

81. Taylor, J.W. The Role of Risk in Consumer Behavior. J. Mark. 1974, 38, 54-60. [CrossRef]

82. Garbarino, E.; Strahilevitz, M. Gender differences in the perceived risk of buying online and the effects of receiving a site recommendation. J. Bus. Res. 2004, 57, 768-775. [CrossRef]

83. Im, I.; Kim, Y.; Han, H.-J. The effects of perceived risk and technology type on users' acceptance of technologies. Inf. Manag. 2008, 45, 1-9. [CrossRef]

84. Marriott, H.R.; Williams, M.D. Exploring consumers perceived risk and trust for mobile shopping: A theoretical framework and empirical study. J. Retail. Consum. Serv. 2018, 42, 133-146. [CrossRef]

85. Shen, C.-C.; Chiou, J.-S. The impact of perceived ease of use on Internet service adoption: The moderating effects of temporal distance and perceived risk. Comput. Hum. Behav. 2010, 26, 42-50. [CrossRef]

86. Featherman, M.; Fuller, M. Applying TAM to e-services adoption: The moderating role of perceived risk. In Proceedings of the 36th Annual Hawaii International Conference on System Sciences, Big Island, HI, USA, 6-9 January 2003; p. 11.

87. Chang, C.C.; Chin, Y.C. The impact of recommendation sources on online purchase intentions: The moderating effects of gender and perceived risk. World Acad. Sci. Eng. Technol. 2010, 66, 111-114.

88. Ramanathan, R. The moderating roles of risk and efficiency on the relationship between logistics performance and customer loyalty in e-commerce. Transp. Res. Part E: Logist. Transp. Rev. 2010, 46, 950-962. [CrossRef]

89. Belanche, D.; Casaló, L.V.; Guinalíu, M. Website usability, consumer satisfaction and the intention to use a website: The moderating effect of perceived risk. J. Retail. Consum. Serv. 2012, 19, 124-132. [CrossRef]

90. Fu, F.Q.; Elliott, M.T. The Moderating Effect of Perceived Product Innovativeness and Product Knowledge on New Product Adoption: An Integrated Model. J. Mark. Theory Pr. 2013, 21, 257-272. [CrossRef] 
91. Bagozzi, R.P.; Dholakia, U.M.; Basuroy, S. How effortful decisions get enacted: The motivating role of decision processes, desires, and anticipated emotions. J. Behav. Decis. Mak. 2003, 16, 273-295. [CrossRef]

92. Perugini, M.; Bagozzi, R.P. The role of desires and anticipated emotions in goal-directed behaviours: Broadening and deepening the theory of planned behaviour. Br. J. Soc. Psychol. 2001, 40, 79-98. [CrossRef]

93. Zeithaml, V.A.; Berry, L.L.; Parasuraman, A. The behavioral consequences of service quality. J. Mark. 1996, 60,31-46. [CrossRef]

94. Kiatkawsin, K.; Han, H. What drives customers' willingness to pay price premiums for luxury gastronomic experiences at michelin-starred restaurants? Int. J. Hosp. Manag. 2019, 82, 209-219. [CrossRef]

95. Chen, C. Perceived risk, usage frequency of mobile banking services. Manag. Serv. Qual. Int. J. 2013, 23, 410-436. [CrossRef]

96. Hwang, J.; Choe, J.Y.J. Exploring perceived risk in building successful drone food delivery services. Int. J. Contemp. Hosp. Manag. 2019, 31, 3249-3269. [CrossRef]

97. Byrne, B.M. Structural Equation Modeling With AMOS, EQS, and LISREL: Comparative Approaches to Testing for the Factorial Validity of a Measuring Instrument. Int. J. Test. 2001, 1, 55-86. [CrossRef]

98. Bagozzi, R.P.; Yi, Y. On the evaluation of structural equation models. J. Acad. Mark. Sci. 1988, 16, 74-94. [CrossRef]

99. Fornell, C.; Larcker, D.F. Evaluating structural equation models with unobservable variables and measurement error. J. Mark. Res. 1981, 18, 39-50. [CrossRef]

100. Hair, J.F.; Black, W.C.; Babin, B.J.; Anderson, R.E.; Tatham, R. Multivariate Data Analysis; Pearson: Uppersaddle River, UK, 2006.

101. Steenkamp, J.E.M.; Baumgartner, H. Assessing Measurement Invariance in Cross-National Consumer Research. J. Consum. Res. 1998, 25, 78-107. [CrossRef]

102. Choi, K.; Hwang, J.; Park, M. Scheduling Restaurant Workers to Minimize Labor Cost and Meet Service Standards. Cornell Hosp. Q. 2009, 50, 155-167. [CrossRef]

103. The Korea Herald. South Korea to Raise Minimum Wage for 2019 by 10.9\%. Available online: http://www. koreaherald.com/view.php?ud=20180714000027 (accessed on 2 September 2020).

104. Lim, N. Consumers' perceived risk: Sources versus consequences. Electron. Commer. Res. Appl. 2003, 2, 216-228. [CrossRef]

105. Hospitality \& Catering News. Robot Waiters, it's Happening Now and Coming to a Restaurant Near You Soon. Available online: https://www.hospitalityandcateringnews.com/2019/09/robot-waiters-happeningnow-coming-restaurant-near-soon/ (accessed on 17 September 2019).

106. Wright, K.B. Researching Internet-based populations: Advantages and disadvantages of online survey research, online questionnaire authoring software packages, and web survey services. J. Comput. Mediat. Commun. 2005, 10, JCMC1034. [CrossRef]

107. Podsakoff, P.M.; MacKenzie, S.B.; Lee, J.Y.; Podsakoff, N.P. Common method biases in behavioral research: A critical review of the literature and recommended remedies. J. Appl. Psychol. 2003, 88, 879-903. [CrossRef]

Publisher's Note: MDPI stays neutral with regard to jurisdictional claims in published maps and institutional affiliations.

(C) 2020 by the authors. Licensee MDPI, Basel, Switzerland. This article is an open access article distributed under the terms and conditions of the Creative Commons Attribution (CC BY) license (http://creativecommons.org/licenses/by/4.0/). 